\title{
ARGILLIZATION OF TOPAZ-BEARING GRANITES IN THE HUB STOCK, HORNÍ SLAVKOV-KRÁSNO SN-W ORE DISTRICT (BOHEMIAN MASSIF, CZECH REPUBLIC)
}

\author{
Martin ŠŤASTNÝ ${ }^{1) *}$ and Miloš RENÉ ${ }^{2)}$ \\ ${ }^{1)}$ Institute of Geology, v.v.i., Academy of Sciences of the Czech Republic, Rozvojová 269, 16500 Prague 6, Czech Republic \\ ${ }^{2)}$ Institute of Rock Structure and Mechanics, v.v.i., Academy of Sciences of the Czech Republic, V Holešovičkách 41, \\ 18209 Prague 8, Czech Republic \\ *Corresponding author's e-mail: stastny@gli.cas.cz
}

\begin{tabular}{l} 
ARtiCle INFO \\
\hline Article history: \\
Received 13 March 2013 \\
Accepted 22 April 2014 \\
Available online 13 May 2014 \\
\hline
\end{tabular}

Keywords:

Bohemian Massif

Saxothuringian Zone

Topaz granite

Argillization

Clay minerals

Dickite

Tosudite

\begin{abstract}
Argillized granites from the Hub stock contain a clay mineral assemblage formed by dickite, illite, tosudite and smectite. These granites occur in the upper part of the topaz granite stock, immediately beneath topaz-mica greisens consisting of quartz, clay minerals, lithium mica (protolithionite) and topaz. Argillized granites are enriched in $\mathrm{Si}$ (up to 78 wt.\% $\left.\mathrm{SiO}_{2}\right), \mathrm{Fe}(0.5$ 3 wt.\% FeO $\mathrm{Fot}_{\text {tot }}$, F (up to 1.6 wt.\%), Rb (830-1380 ppm), Li (515-2317 ppm), Nb (25-435 ppm) and Ta (21-64 ppm), but poor in Th (2-9 ppm), Zr (7-35 ppm) and bulk of REE (3-7 ppm). Newly recognized tosudite was identified on the basis of $d$ (001) $29.4 \AA$ XRD reflection on natural, oriented sample and $31.6 \AA$ reflection after ethylene glycol treatment. The $\mathrm{d}(060)$ reflection appeared at $1.493 \AA$.

The tosudite originated, according to fluid inclusion study of quartz from quartz veins at temperatures of $374-393{ }^{\circ} \mathrm{C}$. The hydrothermal activity of Li-enriched solutions, originated by muscovitization of Li-micas from greisenized topaz-albite granites and greisens was satisfactory for the formation of tosudite. The clay mineral assemblage (dickite, illite and smectite) originated, according to fluid inclusion study of fluorite, at temperatures ranging between $90{ }^{\circ} \mathrm{C}$ and $185^{\circ} \mathrm{C}$.
\end{abstract}

\section{INTRODUCTION}

Hydrothermal alteration of granites connected with the origin of the $\mathrm{Sn}-\mathrm{W}$ greisen deposits is often accompanied by crystallization of clay minerals (Sainsbury, 1960; Pouliot et al., 1978; Psyrillos et al., 2001). The clay mineral assemblage occurs also in hydrothermal altered granitic cupolas of topaz-bearing granites (Creach et al., 1986; Dudoignon et al., 1988; Merceron et al., 1988, 1992). The hydrothermal clay mineral assemblage was apparently controlled by late magmatic albitization and the bulk chemistry of albite-topaz granites. Argillization usually post-dated the greisenization of topaz-bearing granites during decreasing temperature and pressure of later hydrothermal fluids (Merceron et al., 1992).

The Saxothuringian Zone of the Bohemian Massif hosts a number of $\mathrm{Sn}-\mathrm{W}$ deposits (Cínovec/Zinnwald, Krupka, Altenberg, Ehrenfriedersdorf, Přebuz, Horní Slavkov-Krásno) bound to greisenized stocks of the Variscan granitic bodies. Besides the Cornwall ore fields, these deposits were an important European source of tin (and later on, also tungsten) from the Bronze Age until 1991 when the mines of the Altenberg, Ehrenfriedersdorf, Cínovec and Horní Slavkov-Krásno were closed.

In the last decades, numerous mineralogical, petrological and geochemical attempts have been realized in order to assess the origin of the Horní Slavkov-Krásno ores (e.g., Breiter et al., 1999; Dolejš and Štemprok, 2001; Beran and Sejkora, 2006; Jarchovský, 2006; René and Škoda, 2011; Dolníček et al., 2012). However, the post-greisenization fluid activity associated with hydrothermal vein formation and argillization was described only very briefly (Mach, 1979; Melka et al., 1991; Jarchovský, 2006). In this contribution, we provide mineralogical and geochemical data of hydrothermally altered topazalbite granites from the Hub stock, the best exposed and extensively mineralized granite stock of the Horní Slavkov-Krásno ore district.

\section{GEOLOGICAL SETTING}

The Horní Slavkov-Krásno $\mathrm{Sn}-\mathrm{W}$ ore district comprises mineralized topaz granite stocks along the SE margin of the Krudum granite body in the Slavkovský les Mts. area. The Krudum granite body is part of the larger Eibenstock-Karlovy Vary granite pluton of the Western Krušné Hory (Erzgebirge) Mts. (René, 1998; Breiter et al., 1999; Jarchovský, 2006), whose age is ca. 324-295 Ma (Förster et al., 1999 and references therein) (Fig. 1). The inner structure of granite stocks in the Horní Slavkov-Krásno ore district is well stratified, comprising greisens, partially greisenized topaz-albite granites, leucocratic topazalbite granites and layers of alkali-feldspar syenites. According to the most widely accepted genetic models, the topaz-albite granite stocks in the study area represent the apical part of a highly fractionated granite body (e.g., René, 1998; Breiter et al., 1999; Jarchovský, 2006).

Greisens with Sn-W mineralization are developed predominantly in the upper part of the Hub 


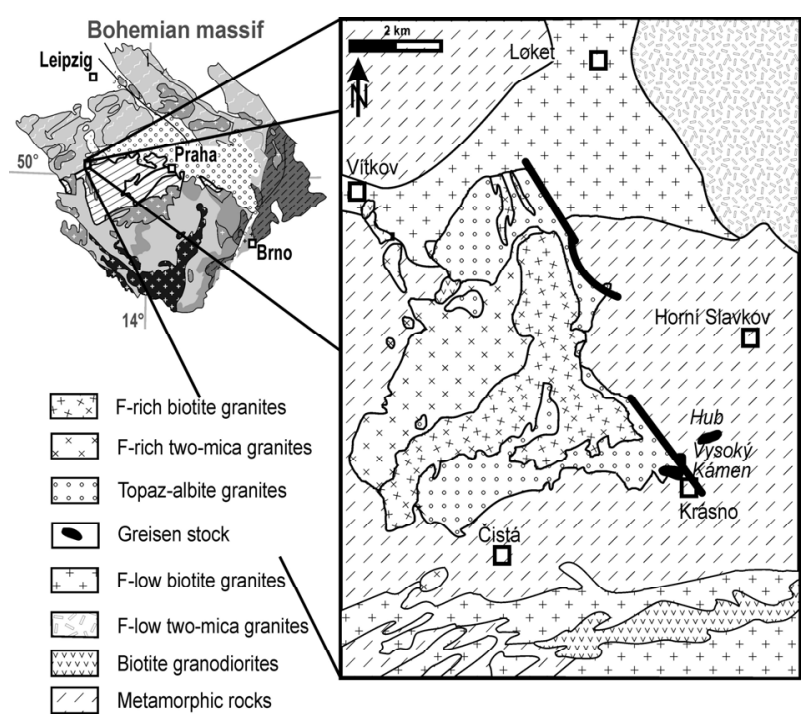

Fig. 1 Geological map of the Krudum granite body.

stock (Fig. 2). The greisens are represented mainly by topaz-Li-mica to Li-mica-topaz greisens, whereas the topaz-quartz, Li-mica-quartz and Li-mica greisens are less frequent. Apical part of the Hub stock consists of topaz-quartz greisens and greisens enriched in sulphides (predominantly arsenopyrite). The topazquartz greisens pass downwards into topaz-Li-mica greisens. Deeper parts of the Hub stock consist of partly greisenized and argillized topaz-albite granites.

The occurrence of $\mathrm{Sn}-\mathrm{W}$ mineralization is controlled by the contact between granite and the gneissic country rock. The highest ore concentrations occur, with some exceptions, in the greisens, and less frequently in the highly greisenized and/or argillized granites. The $\mathrm{Sn}-\mathrm{W}$ mineralization can be subdivided into (1) disseminated-type mineralization, (2) ore pockets, and (3) quartz veins. The disseminated mineralization has a typical content of $0.2-0.3 \mathrm{wt} . \%$ Sn. The ore pockets are globular or even irregular bodies tens of centimetres in size, with a very high proportion of cassiterite. Quartz, Li-micas, fine flakes of muscovite, and clay minerals (dickite, kaolinite, very rare cookeite) are the accompanying minerals of these ore pockets. NE-SW-striking veins are developed mainly in the exocontact of the granite cupola, and less in greisens, where they do not usually exceed $15 \mathrm{~cm}$ in thickness. Besides quartz, they contain cassiterite, wolframite, sometimes also Limicas, apatite, and fluorite with a variable but usually low amount of $\mathrm{Fe}-\mathrm{Cu}-\mathrm{As}-\mathrm{Zn}-\mathrm{Sn}$ sulphides. Relatively rare quartz- and/or apatite-crystal cavities in these veins are sometimes infilled by dickite.

\section{ANALYTICAL METHODS}

The samples used in this study include archive material from underground workings (sampled by M. René and M. Košatka). The sample set for the study of

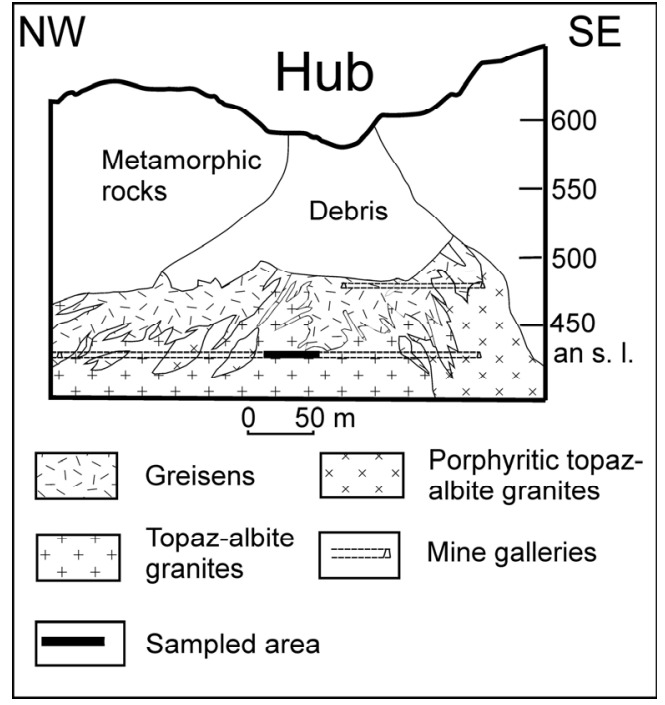

Fig. 2 A cross-section of the Hub stock (after Jarchovský, 2006).

the clay mineral assemblage represents typical examples of hydrothermally altered granites occurring immediately beneath the contact between greisen and granite bodies of the Hub stock (Fig. 2). The representative set of topaz-albite granites from the Hub stock was used for geochemical study.

The whole-rock composition of the topaz-albite granites and their hydrothermally altered equivalents was determined for 52 samples (Table 1). Major elements were determined by X-ray fluorescence spectrometry using PANanalytical Axios Advanced spectrometer at Activation Laboratories Ltd., Ancaster, Canada. The FeO content was measured by titration, whereas the loss on ignition (LOI) was determined gravimetrically at the Analytical Laboratory of the Institute of Rock Structure and Mechanics, v.v.i. (Academy of Sciences of the Czech Republic), Prague, Czech Republic. The F content was determined by using an ion-selective electrode in the same laboratory. Trace elements for representative seven samples (Table 1) were determined by inductively coupled plasma mass spectrometry (ICP MS) using a Perkin Elmer Sciex ELAN 6100 ICP mass spectrometer at Activation Laboratories Ltd. Since the analytical procedure for ICP MS involves lithium metaborate/tetraborate flux fusion, the $\mathrm{Li}$ concentration was analysed separately by atomic absorption spectrometry on a Varian 220 spectrometer at the Institute of Rock Structure and Mechanics, v.v.i.

Electron microprobe analyses of selected minerals (feldspars, micas, topaz, clay minerals) were performed using representative samples of topazalbite granites and their hydrothermally altered equivalents. These analyses were carried out using a CAMECA SX 100 electron microprobe working in WDX mode employing the PAP matrix correction program (Pouchou and Pichoir, 1985) at the Institute 
Table 1 Representative analyses of topaz-albite and argillized granites from the Hub stock.

\begin{tabular}{|c|c|c|c|c|c|c|c|}
\hline $\mathrm{wt} \%$ & Re-999 & Re-1285 & Re-1484 & Кo-52 & Ko-53 & Кo-54 & Кo-55 \\
\hline $\mathrm{SiO}_{2}$ & 71.09 & 74.34 & 73.48 & 78.28 & 77.42 & 75,02 & 75.52 \\
\hline $\mathrm{TiO}_{2}$ & 0.09 & 0.05 & 0.02 & 0.03 & 0.03 & 0.03 & 0.03 \\
\hline $\mathrm{Al}_{2} \mathrm{O}_{3}$ & 16.07 & 15.05 & 15.45 & 12.09 & 11.98 & 13.39 & 13.23 \\
\hline $\mathrm{Fe}_{2} \mathrm{O}_{3}$ & 0.10 & 0.06 & 0.00 & 0.46 & 0.56 & 0.85 & 0.35 \\
\hline $\mathrm{FeO}$ & 1.08 & 0.81 & 0.87 & 1.66 & 1.26 & 1.32 & 1.26 \\
\hline $\mathrm{MnO}$ & 0.08 & 0.05 & 0.07 & 0.32 & 0.21 & 0.15 & 0.11 \\
\hline $\mathrm{MgO}$ & 0.23 & 0.05 & 0.12 & 0.21 & 0.16 & 0.25 & 0.20 \\
\hline $\mathrm{CaO}$ & 0.53 & 0.38 & 0.70 & 1.01 & 1.46 & 0.74 & 1.24 \\
\hline $\mathrm{Na}_{2} \mathrm{O}$ & 3.17 & 3.49 & 2.44 & 0.41 & 0.20 & 0.42 & 0.20 \\
\hline $\mathrm{K}_{2} \mathrm{O}$ & 4.85 & 3.69 & 4.46 & 1.17 & 1.56 & 2.29 & 1.65 \\
\hline $\mathrm{P}_{2} \mathrm{O}_{5}$ & 0.33 & 0.27 & 0.54 & 0.18 & 0.19 & 0.23 & 0.19 \\
\hline $\mathrm{H}_{2} \mathrm{O}^{+}$ & 1.80 & 0.41 & 0.44 & 1.65 & 2.44 & 2.40 & 2.72 \\
\hline $\mathrm{H}_{2} \mathrm{O}^{-}$ & 0.00 & 0.32 & 0.52 & 1.99 & 1.80 & 1.78 & 1.79 \\
\hline F & 0.76 & 0.16 & 0.30 & 0.52 & 0.68 & 0.52 & 0.68 \\
\hline Total & 100.18 & 99.13 & 99.41 & 99.98 & 99.95 & 99.39 & 99.17 \\
\hline \multicolumn{8}{|l|}{ ppm } \\
\hline $\mathrm{U}$ & 20.1 & 22.2 & 9.9 & 13.9 & 5.1 & 11.1 & 16.1 \\
\hline Th & 5.2 & 6.5 & 4.2 & 2.2 & 2.6 & 2.6 & 2.9 \\
\hline Y & 10.4 & 10.1 & 12.5 & 2.6 & 2.9 & 3.4 & 3.7 \\
\hline $\mathrm{Zr}$ & 39 & 40 & 54 & 35 & 24 & 35 & 25 \\
\hline $\mathrm{Ba}$ & 55 & 21 & 6 & 21 & 6 & 8 & 8 \\
\hline $\mathrm{Rb}$ & 1320 & 1160 & 1350 & 692 & 861 & 959 & 886 \\
\hline $\mathrm{Sr}$ & 24 & 13 & 23 & 15 & 19 & 19 & 17 \\
\hline $\mathrm{Li}$ & 803 & 735 & 822 & 1660 & 2300 & 1655 & 1780 \\
\hline $\mathrm{La}$ & 3.54 & 3.77 & 3.75 & 1.59 & 1.40 & 1.59 & 1.55 \\
\hline $\mathrm{Ce}$ & 8.09 & 8.70 & 9.32 & 1.96 & 1.61 & 1.95 & 2.13 \\
\hline $\operatorname{Pr}$ & 0.95 & 1.03 & 1.07 & 0.23 & 0.19 & 0.24 & 0.25 \\
\hline $\mathrm{Nd}$ & 4.01 & 4.22 & 3.75 & 1.12 & 1.01 & 1.21 & 1.29 \\
\hline Sm & 1.38 & 1.39 & 1.37 & 0.34 & 0.32 & 0.38 & 0.40 \\
\hline $\mathrm{Eu}$ & 0.09 & 0.08 & 0.04 & 0.01 & 0.01 & 0.01 & 0.01 \\
\hline Gd & 1.46 & 1.42 & 1.32 & 0.29 & 0.33 & 0.34 & 0.35 \\
\hline $\mathrm{Tb}$ & 0.33 & 0.30 & 0.35 & 0.07 & 0.08 & 0.09 & 0.09 \\
\hline Dy & 1.85 & 1.74 & 2.20 & 0.45 & 0.49 & 0.55 & 0.61 \\
\hline Ho & 0.31 & 0.31 & 0.41 & 0.07 & 0.07 & 0.09 & 0.09 \\
\hline $\mathrm{Er}$ & 1.03 & 0.98 & 1.30 & 0.20 & 0.22 & 0.25 & 0.27 \\
\hline $\mathrm{Tm}$ & 0.18 & 0.18 & 0.25 & 0.04 & 0.05 & 0.06 & 0.06 \\
\hline $\mathrm{Yb}$ & 1.25 & 1.16 & 1.82 & 0.27 & 0.31 & 0.37 & 0.36 \\
\hline $\mathrm{Lu}$ & 0.17 & 0.15 & 0.23 & 0.04 & 0.04 & 0.05 & 0.04 \\
\hline$\Sigma$ REE & 24.64 & 25.44 & 27.18 & 6.67 & 6.12 & 7.17 & 7.50 \\
\hline $\mathrm{La}_{\mathrm{N}} / \mathrm{Yb}_{\mathrm{N}}$ & 1.91 & 2.20 & 3.46 & 3.98 & 3.05 & 2.90 & 2.91 \\
\hline $\mathrm{Eu} / \mathrm{Eu}^{*}$ & 0.20 & 0.18 & 0.05 & 0.09 & 0.05 & 0.04 & 0.06 \\
\hline
\end{tabular}

Topaz- albite granites: Re-999 - 4. level, gallery M-4040000, Re-1285 - borehole HU-26, 507.50 m, Re-1484 - 4. level, gallery M-404000 argillized granite: Ko-52 - 4. level, gallery M-4014337, Ko-53 - 4. level, gallery M-4014137, Ko-54 4. level, gallery CH-4070, Ko-55 - 4. level, gallery CH-4053

of Geology, v.v.i. (Academy of Sciences of the Czech Republic). The operating conditions were $15 \mathrm{kV}$ acceleration voltage, $15 \mathrm{nA}$ beam current, and $2 \mu \mathrm{m}$ beam diameter. Counting times on the peaks were 10 30 seconds depending on the element. Background counts were measured in each case in half the time for peak measurement on both sides of the peak. Calibrations were done using standard sets from SPI. Standards included diopside ( $\mathrm{Ca}, \mathrm{Mg})$, fluorite $(\mathrm{F})$, jadeite $(\mathrm{Na}, \mathrm{Al})$, leucite $(\mathrm{K})$, magnetite $(\mathrm{Fe})$, quartz (Si), $\mathrm{RbCl}(\mathrm{Rb})$, rhodonite $(\mathrm{Mn})$, rutile (Ti), spinel $(\mathrm{Cr})$ and tugtupite $(\mathrm{Cl})$. Detection limits for these elements are as follows: F $0.09-0.15$ wt.\%, other elements $0.03-0.20$ wt.\%. Mineral formulae were recalculated using the MINPET 2.0 software. Formulae of Li-micas, illite and smectite were calculated in relation to $24(\mathrm{O}, \mathrm{OH})$ atoms per formula unit (apfu), formulae of dickite were calculated on the basis of $18(\mathrm{O}, \mathrm{OH})$ apfu and formulae of tosudite were calculated on basis of $36(\mathrm{O}, \mathrm{OH})$ apfu.

Whole-rock samples enriched in clay minerals were used for sampling of clay mineral fractions. The size fraction of clay minerals in size below $4 \mu \mathrm{m}$ was prepared by conventional sedimentation method. $\mathrm{X}$ - ray diffraction (XRD) analyses of clay minerals in clay-size fractions were obtained at Institute of Geology, v.v. i. (Academy of Sciences of the Czech Republic) on randomly oriented and sedimented air- 


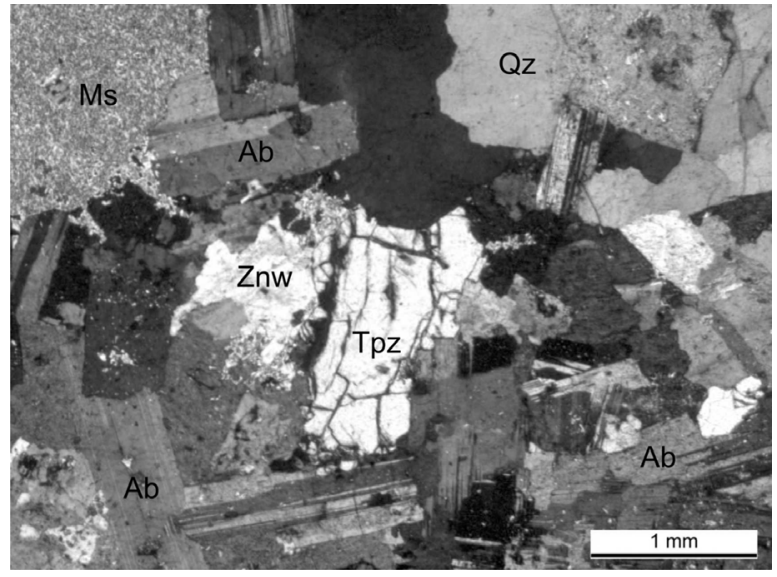

Fig. 3 Partly greisenized topaz-albite granites with aggregates of polysynthetic twinned albites, partly argillized K-feldspar and altered $\mathrm{Li}$ mica, crossed polars. Ab - albite, Qz - quartz, Znw - Li-mica, Kfs - potassium feldspar, Ms - white mica, Tpz - topaz. (Photo M. René)

dry untreated, ethylene glycol solvated and by various temperatures heated $\left(500^{\circ} \mathrm{C}, 700{ }^{\circ} \mathrm{C}\right)$ samples using a Bruker D8 Discover diffractometer with $\mathrm{CuK}_{\alpha}$ radiation $(40 \mathrm{kV}, 40 \mathrm{~mA}), \mathrm{Ni}$ filter standard set, scanning speed $1 \% \mathrm{~min}$, step size 0.02 and spreading in between 3 to $35^{\circ} 2 \theta$ for oriented samples.

The thermal behaviour of the clay fraction was characterized by differential thermal analysis (DTA) and thermogravimetric analysis (TGA) at a heating rate of $10^{\circ} \mathrm{C} / \mathrm{min}$, using a MOM derivatograph at the Institute of Rock Structure and Mechanics, v.v.i. (Academy of Sciences of the Czech Republic).

\section{PETROGRAPHY}

Partly greisenized topaz-albite granite is a medium grained, equigranular rock consisting of quartz, albite $\left(\mathrm{An}_{0-2}\right)$, potassium feldspar, lithium mica and topaz. Fluorapatite, zircon, $\mathrm{Nb}-\mathrm{Ta}-\mathrm{Ti}$ oxides, xenotime-(Y), monazite-(Ce), uraninite and coffinite are common accessory minerals. Cassiterite occurs as a very rare accessory mineral. Grain size of the individual minerals is $1-3 \mathrm{~mm}$. Albite frequently occurs in medium- to fine-grained aggregates, which show polysynthetic twinning. Potassium feldspar is usually partly altered and contains very fine inclusions of illite and dickite (Fig. 3). Some K-feldspar phenocrysts are perthitic. Topaz occurs in the form of irregular grains and/or anhedral aggregates, rimmed by a mixture of white mica and clay minerals (dickite) (Fig. 4).

Highly variable greisenized and argillized granite is a medium- to fine grained, equigranular rock consisting of quartz, clay minerals, lithium mica, white mica and topaz. Quartz occurs in two generations. The older quartz generation (quartz I) is formed by fine- to medium grained aggregates, and

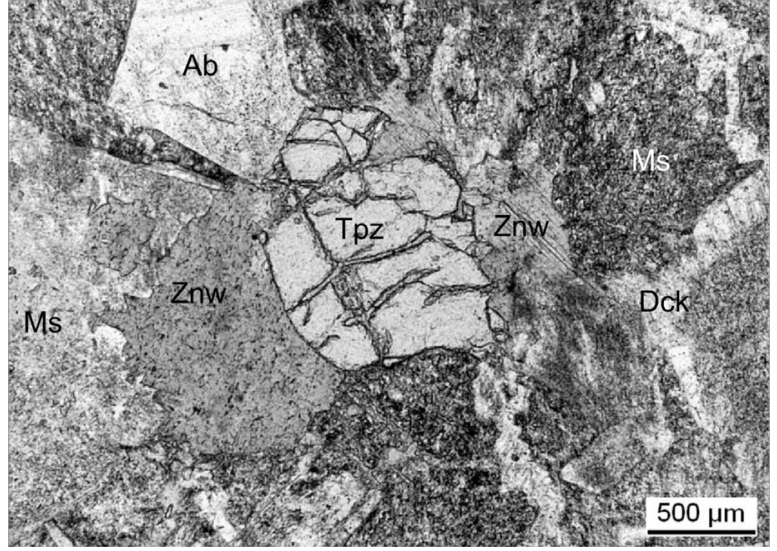

Fig. 4 Partly greisenized topaz-albite granites with a typical topaz-Li-mica assemblage. White mica and clay mineral assemblage rim the topaz grains. Qz - quartz, Znw - Li-mica, Tpz - topaz, Ab - albite, Ms - white mica, Dck - dickite. (Photo M. René)

the younger quartz (quartz II), originated during greisenization, frequently forms distinctly larger anhedral grains. Some samples of these granites contain also low, but highly variable amounts of albite and potassium feldspar. Both feldspars are usually nearly quite altered in the clay mineral assemblage (white mica, dickite, illite). The Li-mica occurs in two generations, older magmatic (Li-mica I) and the younger Li-mica II, originated during post-magmatic greisenization. The younger Li-mica frequently forms irregular aggregates of subhedral tables. Topaz occurs as irregular, anhedral grained aggregates, which are surrounded by very fine aggregates of white mica and clay minerals.

Argillized granites are usually medium-grained, disaggregated rocks consisting quartz, Li-mica, topaz, rests of feldspars grains and highly variable amounts of white mica and clay minerals (dickite, illite, tosudite). Li-mica is usually partly altered into white mica, illite and chlorite. White mica fine-grained aggregates together with the clay minerals assemblage occur as borders of topaz grains (Fig. 5). The clay mineral assemblage occurs also in the form of pseudomorphs after feldspar grains and/or as fissure filling in altered granites. The abundant irregular fissures are filled with quartz and fluorite (Fig. 6). Fluorapatite, zircon, $\mathrm{Nb}-\mathrm{Ta}-\mathrm{Ti}$ oxides, xenotime-(Y) and monazite- $(\mathrm{Ce})$ are rare accessory minerals.

\section{GEOCHEMISTRY}

Partly greisenized topaz-albite granite is a highly peraluminous rock with an aluminium saturation index (ASI) ranging from 1.1 to 1.5. Compared to common Ca-poor granites (Chappell and Hine, 2006), it is enriched in incompatible elements such as Li (160-820 ppm), Rb (830-1500 ppm), Cs (38- 


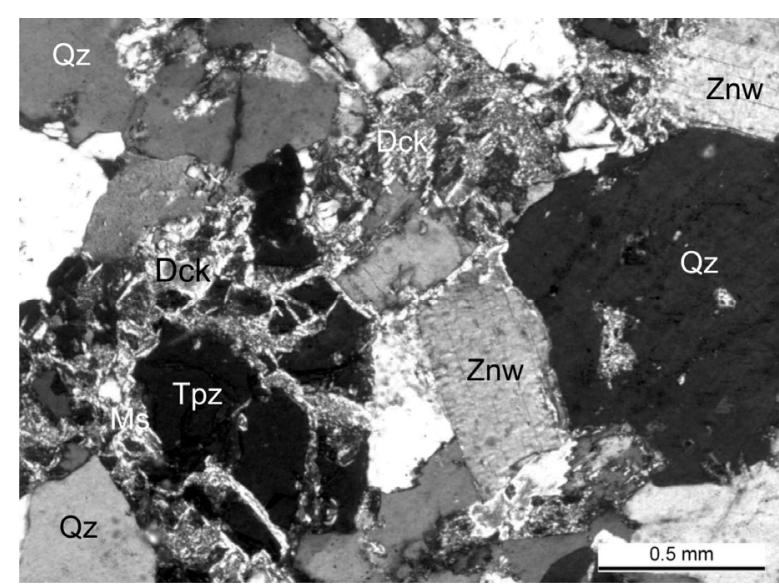

Fig. 5 Argillized topaz-albite granite with Li-mica and topaz rimmed by white mica and clay mineral assemblage. Qz - quartz, Znw - Limica, Tpz - topaz, Ms - white mica, Dck dickite. (Photo M. René)

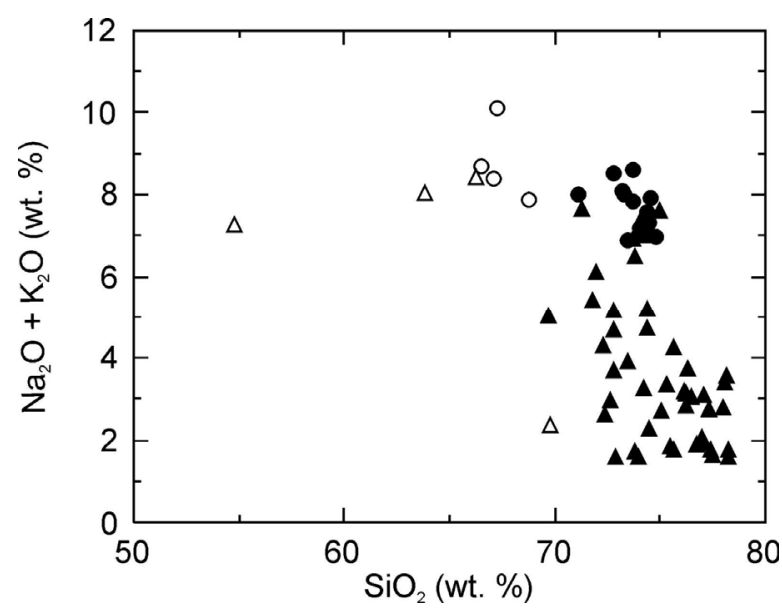

- Topaz-albite granite, Hub stock

- Argillized granite, Hub stock

- Topaz-abite granite, Echassières granitic cupola, France

$\triangle$ Argillized granite, Echassières granitic cupola, France

Fig. 7 The $\mathrm{K}_{2} \mathrm{O}+\mathrm{Na}_{2} \mathrm{O}$ vs. $\mathrm{SiO}_{2}$ plot for topazalbite granites and their argillized equivalents from the Hub stock. Analyses of granites from the Echassières granite cupola, France, were used for comparison (Merceron et al., 1992).

$150 \mathrm{ppm}), \mathrm{Sn}$ (19-6200 ppm), Nb (18-83 ppm), Ta (8-53 ppm) and $\mathrm{W}(4-62 \mathrm{ppm})$, but poor in $\mathrm{Mg}$ (0.1-0.2 wt.\% $\mathrm{MgO}), \mathrm{Ca}(0.3-1.0$ wt.\% $\mathrm{CaO})$, $\mathrm{Sr}(12-50 \mathrm{ppm}), \mathrm{Ba}$ (21-81 ppm) and $\mathrm{Zr} \quad(20-$ $55 \mathrm{ppm})$. Granite is distinctly enriched in $\mathrm{P}(0.3$ 0.4 wt. $\left.\% \mathrm{P}_{2} \mathrm{O}_{5}\right)$ and $\mathrm{F}(0.1-0.8$ wt. $\% \mathrm{~F})$. A high degree of magmatic fractionation is reflected in the low $\mathrm{K} / \mathrm{Rb}$ value (15-47).

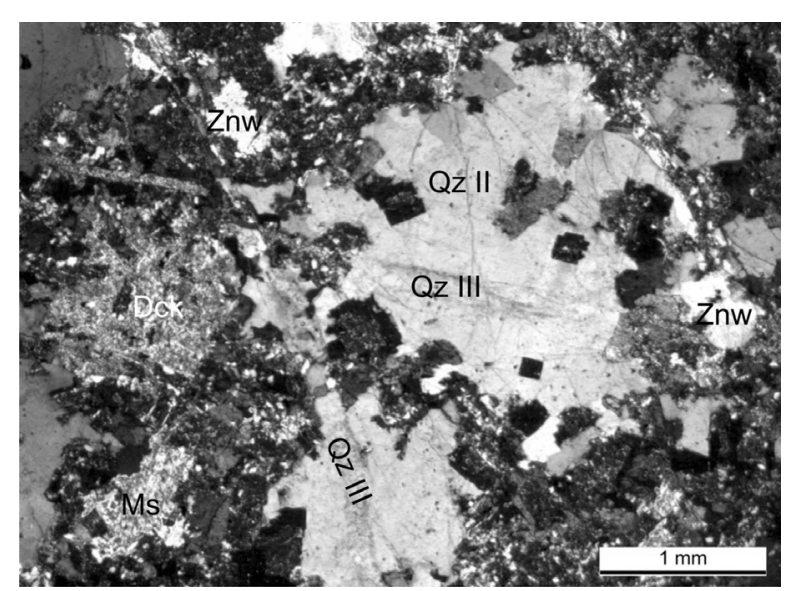

Fig. 6 Argillized topaz-albite granites with finegrained white mica, clay mineral assemblage, larger quartz II grains and fine fissures filled with quartz III, crossed polars. Qz - quartz, Ms - white mica, Znw - Li-mica, Dck dickite. (Photo M. René)

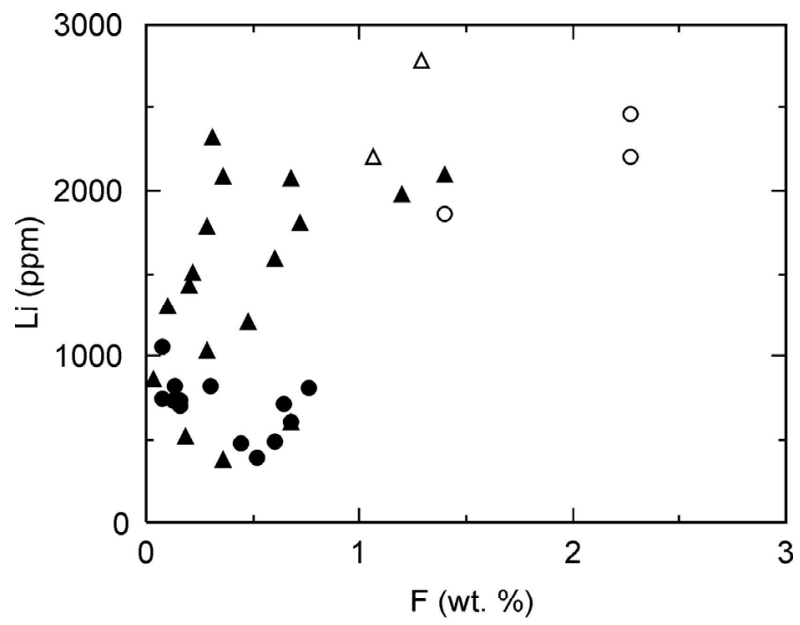

- Topaz-albite granite, Hub stock

- Argillized granite, Hub stock

- Topaz-abite granite, Echassières granitic cupola, France

$\Delta$ Argillized granite, Echassières granitic cupola,

France

Fig. 8 The Li vs. F plot for topaz-albite granites and their argillized equivalents from the Hub stock. Analyses of granites from the Echassières granite cupola, France, were used for comparison (Merceron et al., 1992).

Compared to partly greisenized topaz-albite granite, the highly variable greisenized and argillized granite is enriched in $\mathrm{Si}$ (up to 78 wt. $\% \mathrm{SiO}_{2}$ ), $\mathrm{Fe}\left(0.5-3.3\right.$ wt. $\% \mathrm{FeO}_{\text {tot. }}$ ), $\mathrm{F}$ (up to 1.64 wt. \%), $\mathrm{Rb}$ (830-1380 ppm), Li (515-2317 ppm), Nb (25$435 \mathrm{ppm})$ and Ta (21-64 ppm), but poor in Th (2$9 \mathrm{ppm}), \mathrm{Zr}$ (7-35 ppm) and bulk of REE (3-7 ppm) (Figs. 7-9). 


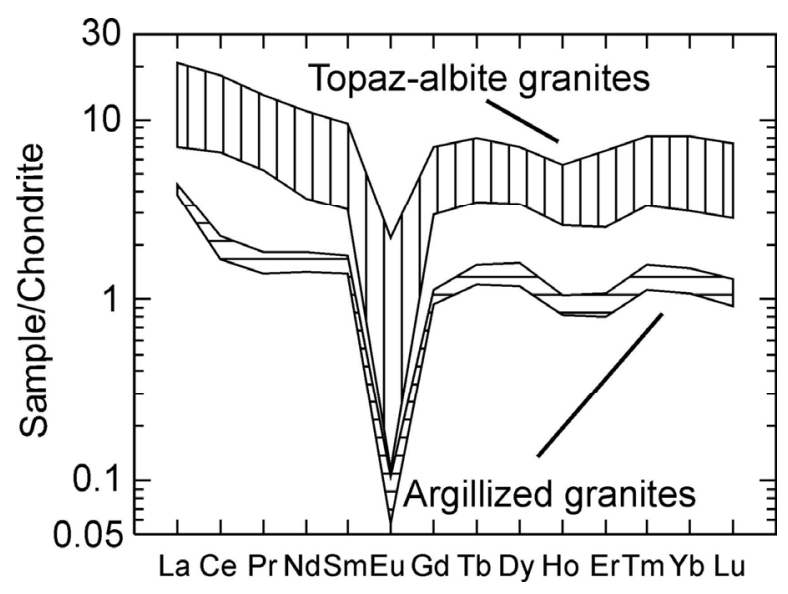

Fig. 9 Chondrite-normalized REE patterns for topaz-albite granites and their argillized equivalents from the Hub stock. Normalizing values are from Taylor and McLennan (1985). also by the DTA. On the DTA curve the endothermic peak at $700{ }^{\circ} \mathrm{C}$ and the exothermic peak at $980{ }^{\circ} \mathrm{C}$ occur. These peaks are significant for the presence of dickite (Fig. 11).

Tosudite was recognized by XRD analysis on the basis of d (001) reflection. Diffractograms of air-dried oriented sedimented sample indicated a mean basal reflection of $29.4 \AA$, which corresponds to one chlorite layer $(14.2 \AA)$ plus one smectite layer $(15.2 \AA)$ associated on a regular basis. After ethylene glycol solvation, this reflection expanded to a d (001) reflection of $31.6 \AA$. When heated to $500{ }^{\circ} \mathrm{C}$, the $\mathrm{d}$ (001) reflection decreased to $23.1 \AA$ (Table 2 ). The $\mathrm{d}(060)$ reflection appeared at $1.493 \AA$. These reflections are closer to the reflections reported for tosudite - a regularly interstratified mineral of dioctahedral chlorite and dioctahedral smectite (e.g., Ichikawa and Shimoda, 1976; Reynolds, 1988; Bartier et al., 2008).

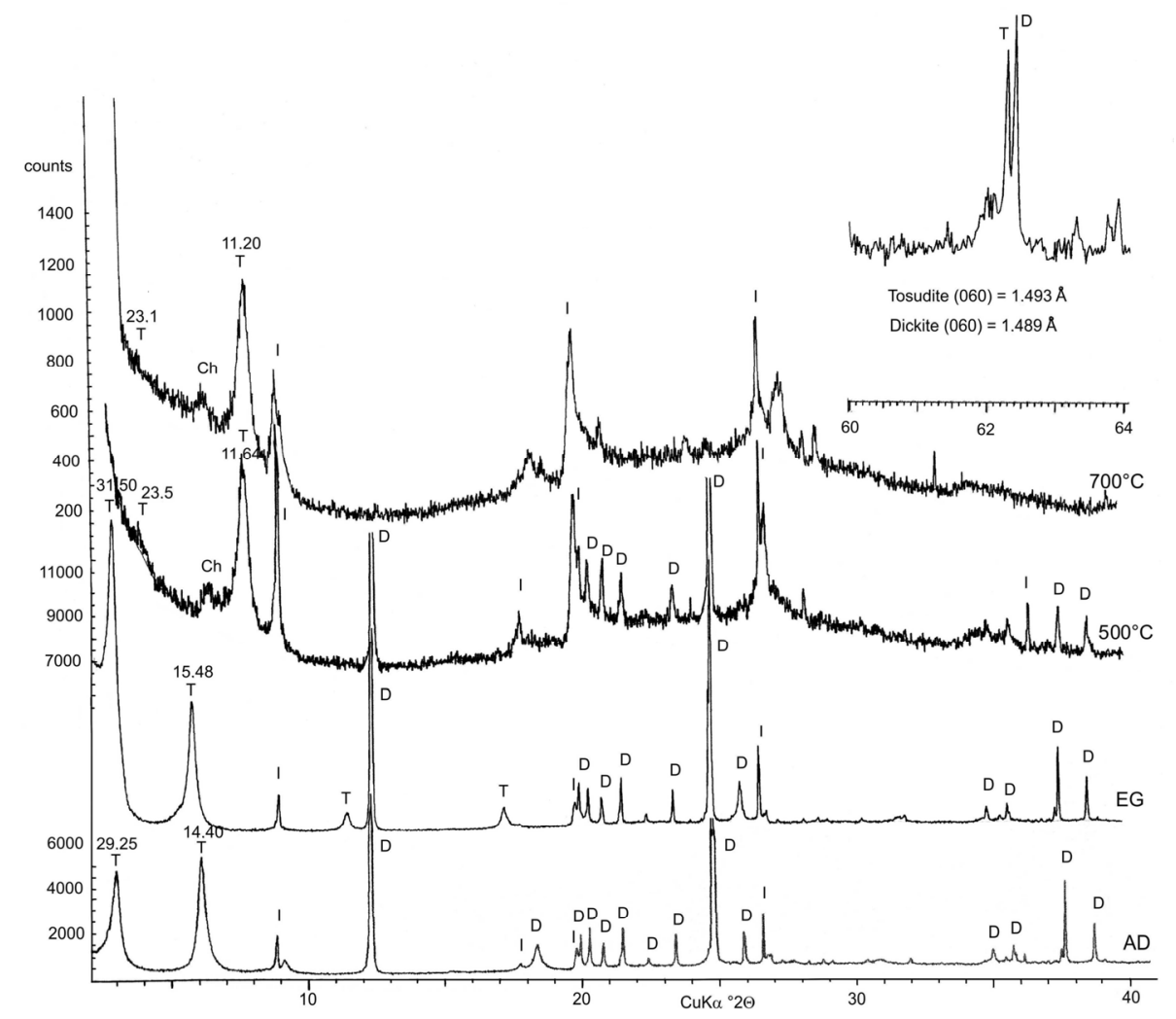

Fig. 10 X-ray powder diffraction patterns of dickite, tosudite, illite and chlorite from argillized granite, Hub stock (D - dickite, T - tosudite, I - illite, Ch chlorite, AD - air-dried untreated sample, EG - ethylene glycol solvated sample).

\section{MINERALOGY}

Dickite and tosudite and small quantities of illite and chlorite were identified in selected samples of argillized granites using the XRD analysis. For dickite, two distinctly diagnostic reflections (3.79 $\AA$ and $3.43 \AA$ ) were found, which are absent in kaolinite (Fig. 10). The occurrence of dickite was documented

\section{COMPOSITION OF LI-MICA AND CLAY MINERALS}

Li-micas are present in all investigated rock types, with considerable enrichment in greisenized and argillized granites. This enrichment is also displayed by distinctly higher values of lithium in whole-rock samples (up to $2317 \mathrm{ppm} \mathrm{Li}$ ). The 
Table 2 X-ray diffraction data of tosudite from the Hub stock.

\begin{tabular}{|c|c|c|c|c|c|c|c|c|}
\hline \multirow[b]{2}{*}{ hkl } & \multicolumn{2}{|c|}{$\begin{array}{l}\text { Natural sample } \\
\text { (air dried) }\end{array}$} & \multicolumn{2}{|c|}{$\begin{array}{c}\text { Ethylene glycol } \\
\text { treatment }\end{array}$} & \multicolumn{2}{|c|}{ Heated $500^{\circ} \mathrm{C}$} & \multicolumn{2}{|c|}{ Heated $700^{\circ} \mathrm{C}$} \\
\hline & $\mathrm{d}(\AA)$ & I & $\mathrm{d}(\AA)$ & I & $\mathrm{d}(\AA)$ & I & $\mathrm{d}(\AA)$ & I \\
\hline 001 & 29.4 & 100 & 31.6 & 100 & 23.5 & 3 & 23.1 & 3 \\
\hline 002 & 14.66 & 60 & 15.56 & 57 & 11.64 & 100 & 11.21 & 100 \\
\hline 003 & 9.825 & 2.6 & 10.163 & 5.3 & & & & \\
\hline 004 & 7.417 & 3.4 & 7.789 & 8.1 & & & & \\
\hline 005 & 5.905 & 0.2 & & & 4.690 & 1.4 & 4.926 & 1.6 \\
\hline 006 & 4.921 & 9.2 & 5.185 & 9.2 & 3.794 & 20.1 & 3.685 & 0.2 \\
\hline 007 & & & 4.450 & 19.7 & & & 3.276 & 5.2 \\
\hline 008 & 3.691 & 2.5 & 3.882 & 14.9 & & & 2.932 & 1.4 \\
\hline 009 & 3.271 & 2.4 & 3.453 & 18.2 & 2.561 & 8.8 & 2.660 & 0.1 \\
\hline 0010 & 2.937 & 2.7 & & & 2.326 & 21.6 & & \\
\hline 0011 & & & 2.826 & 1.8 & & & & \\
\hline 0012 & 2.455 & 0.5 & & & & & & \\
\hline$\phi \mathrm{d}(001)$ & $29.47 \AA$ & & $31.09 \AA$ & & $23.22 \AA$ & & $23.22 \AA$ & \\
\hline
\end{tabular}

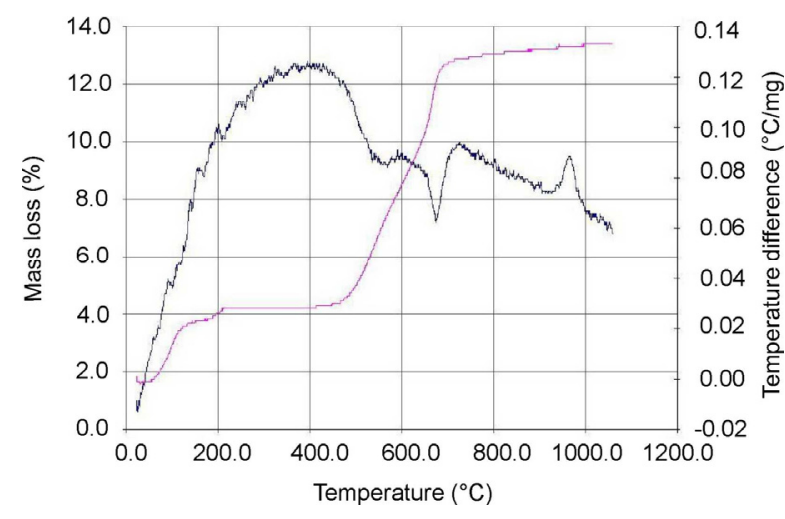

Fig. 11 Differential thermal analysis and thermal gravimetric analysis of dickite from argillized granite, Hub stock.

chemical composition obtained by electron microprobe (EMPA) and empirical formulae of selected Li-micas are presented in Table 3. In the classification diagram of Tischendorf et al. (1997), data points of Li-micas fall to the protolithionite field. Compared to Li-micas from slightly greisenized topaz-albite granites, the Li-micas from greisenized and argillized granites are enriched in $\mathrm{Li}(0.83$ $1.12 \mathrm{apfu}$ ) and F (4.82-5.95 apfu) (Fig. 12), and depleted in Ti (0.03-0.05 apfu) (Fig. 13).

White micas, which are relatively rare in slightly greisenized topaz-albite granites, are depleted in Fe and $\mathrm{Mg}$ compared to the ideal Tschermak's substitution line $(\mathrm{Si}=\mathrm{f}(\mathrm{Fe}+\mathrm{Mg}))$ (Fig. 14). The content of phengite component is therefore very low. Chemical data for illite obtained by the EMPA are presented in Table 4. Octahedral occupancy of illite minerál formulae ranges from 4.00 to 4.10 . In a $\mathrm{Si}=\mathrm{f}(\mathrm{Fe}+\mathrm{Mg})$ diagram, illite plots similar as white

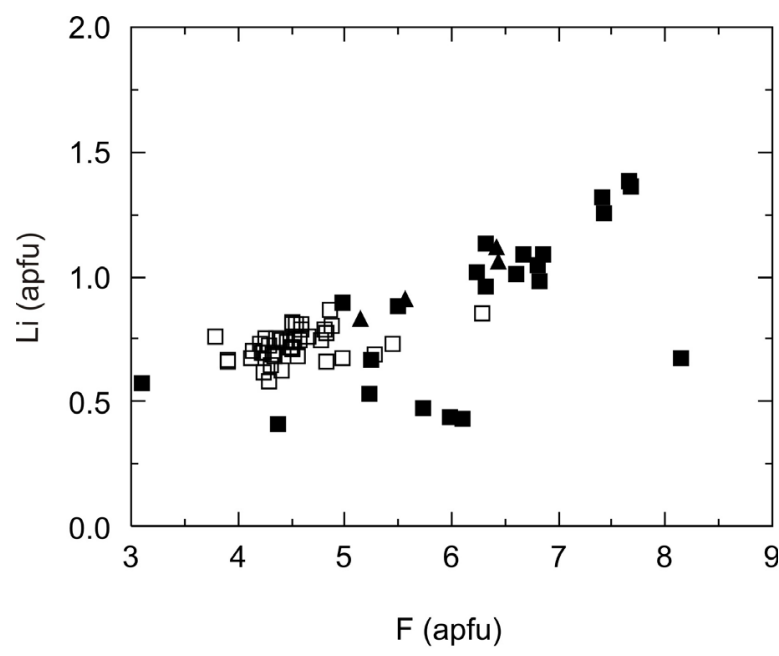

Topaz-albite granite, Hub stock

\ Argillized granite, Hub stock

- Topaz-albite granite, Krušné Hory/Erzgebirge Mts.

Fig. 12 The Li vs. F plot for Li-micas from topazalbite granites and their argillized equivalents. For comparison with other Li-micas from topaz-albite granites of the Krušné Hory/Erzgebirge batholith, representative Limica analyses were used (Podlesí, Hora svaté Kateřiny, Eibenstock, Pobershau, Cínovec) (Breiter, 2002, 2008; Pechar and Rykl, 1992; Tischendorf et al., 1997).

mica samples, distinctly below the ideal phengitic substitution line (Fig. 14).

Chemical data for dickite and smectite obtained by the EMPA are presented in Table 5. Enrichment in Fe (0.02-0.26 apfu), Ca (0.00-0.07 apfu) and K (0.00- 
Table 3 Representative analyses of lithium mica from the Hub stock.

\begin{tabular}{|c|c|c|c|c|c|c|c|c|}
\hline wt. $\%$ & $1007-2$ & $1283-8$ & $1285-1$ & $1285-4$ & $55-24$ & $55-25$ & $55-26$ & $55-27$ \\
\hline $\mathrm{SiO}_{2}$ & 41.53 & 42.53 & 41.85 & 42.06 & 45.81 & 43.89 & 46.53 & 43.01 \\
\hline $\mathrm{TiO}_{2}$ & 0.74 & 0.54 & 0.70 & 0.74 & 0.30 & 0.43 & 0.25 & 0.36 \\
\hline $\mathrm{Al}_{2} \mathrm{O}_{3}$ & 24.61 & 23.79 & 24.68 & 24.84 & 22.20 & 22.75 & 21.50 & 23.61 \\
\hline $\mathrm{FeO}$ & 13.69 & 13.21 & 13.63 & 12.82 & 13.74 & 15.13 & 13.43 & 16.36 \\
\hline $\mathrm{MnO}$ & 0.76 & 0.58 & 0.40 & 0.51 & 0.56 & 0.60 & 0.61 & 0.81 \\
\hline $\mathrm{MgO}$ & 0.46 & 0.51 & 0.61 & 0.57 & 0.13 & 0.13 & 0.17 & 0.12 \\
\hline $\mathrm{CaO}$ & 0.05 & 0.01 & 0.00 & 0.00 & 0.01 & 0.00 & 0.02 & 0.00 \\
\hline $\mathrm{Na}_{2} \mathrm{O}$ & 0.30 & 0.40 & 0.31 & 0.28 & 0.20 & 0.26 & 0.22 & 0.19 \\
\hline $\mathrm{K}_{2} \mathrm{O}$ & 9.12 & 9.34 & 9.88 & 9.91 & 9.98 & 9.86 & 9.93 & 9.98 \\
\hline $\mathrm{Li}_{2} \mathrm{O}$ calc. & 2.37 & 2.65 & 2.46 & 2.52 & 3.60 & 3.04 & 3.80 & 2.79 \\
\hline $\mathrm{F}$ & 4.29 & 4.87 & 4.58 & 4.65 & 6.44 & 5.56 & 6.42 & 5.14 \\
\hline $\mathrm{Cl}$ & 0.02 & 0.01 & 0.01 & 0.01 & 0.00 & 0.00 & 0.00 & 0.00 \\
\hline $\mathrm{O}=(\mathrm{F}, \mathrm{Cl})$ & 1.81 & 2.05 & 1.93 & 1.96 & 2.71 & 2.34 & 2.70 & 2.16 \\
\hline Total & 96.13 & 96.39 & 97.18 & 96.95 & 100.26 & 99.31 & 100.18 & 100.21 \\
\hline \multicolumn{9}{|l|}{ apfu } \\
\hline $\mathrm{Si}^{4+}$ & 6.31 & 6.44 & 6.31 & 6.33 & 6.70 & 6.53 & 6.79 & 6.38 \\
\hline $\mathrm{Al}^{\mathrm{IV}}$ & 1.69 & 1.56 & 1.69 & 1.67 & 1.31 & 1.47 & 1.21 & 1.62 \\
\hline $\mathrm{Al}^{\mathrm{VI}}$ & 2.71 & 2.68 & 2.69 & 2.73 & 2.52 & 2.51 & 2.48 & 2.51 \\
\hline $\mathrm{Ti}^{4+}$ & 0.09 & 0.06 & 0.08 & 0.08 & 0.03 & 0.05 & 0.03 & 0.04 \\
\hline $\mathrm{Fe}^{2+}$ & 1.74 & 1.67 & 1.72 & 1.61 & 1.68 & 1.88 & 1.64 & 2.03 \\
\hline $\mathrm{Mn}^{2+}$ & 0.10 & 0.07 & 0.05 & 0.07 & 0.07 & 0.08 & 0.08 & 0.10 \\
\hline $\mathrm{Mg}^{2+}$ & 0.10 & 0.12 & 0.14 & 0.13 & 0.03 & 0.03 & 0.04 & 0.03 \\
\hline $\mathrm{Ca}^{2+}$ & 0.01 & 0.00 & 0.00 & 0.00 & 0.00 & 0.00 & 0.00 & 0.00 \\
\hline $\mathrm{Na}^{1+}$ & 0.09 & 0.11 & 0.09 & 0.08 & 0.06 & 0.08 & 0.06 & 0.06 \\
\hline $\mathrm{K}^{1+}$ & $\begin{array}{l}0.07 \\
1.77\end{array}$ & 1.80 & $\begin{array}{l}.09 \\
1.90\end{array}$ & $\begin{array}{l}0.00 \\
1.90\end{array}$ & $\begin{array}{l}.00 \\
1.86\end{array}$ & $\begin{array}{l}0.00 \\
1.87\end{array}$ & $\begin{array}{l}0.00 \\
1.85\end{array}$ & $\begin{array}{l}1.80 \\
1.89\end{array}$ \\
\hline $\mathrm{Li}^{1+}$ & 0.72 & 0.81 & 0.75 & 0.76 & 1.06 & 0.91 & 1.12 & 0.83 \\
\hline $\mathrm{F}^{1-}$ & 4.12 & 4.66 & 4.37 & 4.43 & 5.95 & 5.23 & 5.92 & 4.82 \\
\hline $\mathrm{Cl}^{1-}$ & 0.01 & 0.01 & 0.01 & 0.01 & 0.00 & 0.00 & 0.00 & 0.00 \\
\hline $\mathrm{O}$ & 24 & 24 & 24 & 24 & 24 & 24 & 24 & 24 \\
\hline $\mathrm{Fe} /(\mathrm{Fe}+\mathrm{Mg})$ & 0.94 & 0.94 & 0.93 & 0.93 & 0.98 & 0.98 & 0.98 & 0.99 \\
\hline
\end{tabular}

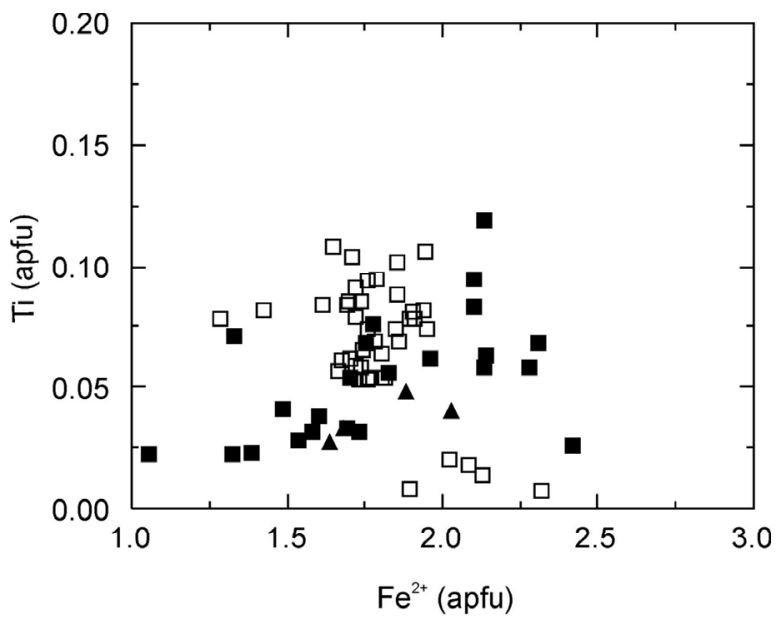

Topaz-albite granite, Hub stock

- Argillized granite, Hub stock

- Topaz-albite granite, Krušné Hory/Erzgebirge Mts

Fig. 13 The Ti vs. Fe plot for Li-micas from topazalbite granites and their argillized equivalents. For comparison with other Li-micas from topaz-albite granites of the Krušné Hory/Erzgebirge batholith, representative Limica analyses were used (Podlesí, Hora svaté Kateřiny, Eibenstock, Pobershau, Cínovec) (Breiter, 2002, 2008; Pechar and Rykl, 1992; Tischendorf et al., 1997).

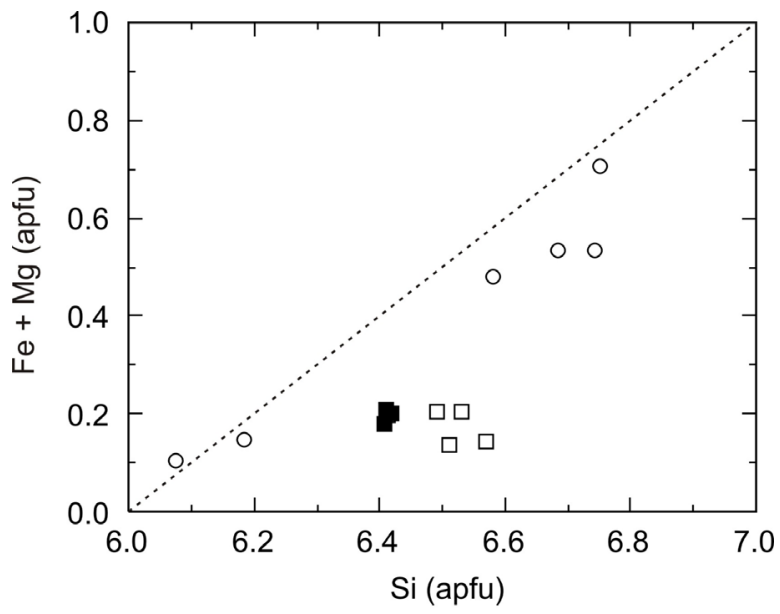

- White mica, Hub stock $\quad \square \quad$ Illite, Hub stock

- Illite, Soultz-sous-Forêts, France

Fig. 14 Composition of white mica and illite in a $\mathrm{Si}=$ $\mathrm{f}(\mathrm{Fe}+\mathrm{Mg})$ plot. The ideal Tschermak's substitution is drawn in a dashed line (Guidotti, 1984). Analyses of illite from argillized granites of the Soultz-sous-Forêts granite body, France, were used for comparison (Ledésert et al., 1999; Bartier et al., 2008). 
Table 4 Representative analyses of white mica and illite from topaz-albite granite and argillized granite of the Hub stock.

\begin{tabular}{|c|c|c|c|c|c|c|c|}
\hline wt. $\%$ & Hub-24 & Hub-27 & Hub-30 & Hub-18 & Hub-19 & Hub-38 & Hub-41 \\
\hline $\mathrm{SiO}_{2}$ & 48.97 & 48.30 & 48.87 & 50.90 & 50.94 & 50.42 & 49.72 \\
\hline $\mathrm{TiO}_{2}$ & 0.05 & 0.06 & 0.05 & 0.03 & 0.01 & 0.03 & 0.02 \\
\hline $\mathrm{Al}_{2} \mathrm{O}_{3}$ & 35.08 & 34.38 & 34.69 & 34.83 & 35.52 & 35.18 & 36.12 \\
\hline $\mathrm{Cr}_{2} \mathrm{O}_{3}$ & 0.01 & 0.01 & 0.01 & 0.03 & 0.00 & 0.00 & 0.01 \\
\hline $\mathrm{FeO}$ & 1.28 & 1.41 & 1.28 & 0.98 & 1.42 & 1.01 & 1.30 \\
\hline $\mathrm{MnO}$ & 0.01 & 0.04 & 0.06 & 0.19 & 0.16 & 0.19 & 0.18 \\
\hline $\mathrm{MgO}$ & 0.21 & 0.27 & 0.30 & 0.19 & 0.28 & 0.06 & 0.30 \\
\hline $\mathrm{CaO}$ & 0.06 & 0.05 & 0.05 & 0.29 & 0.46 & 0.06 & 0.42 \\
\hline $\mathrm{Na}_{2} \mathrm{O}$ & 0.16 & 0.16 & 0.19 & 0.12 & 0.15 & 0.11 & 0.06 \\
\hline $\mathrm{K}_{2} \mathrm{O}$ & 10.14 & 10.10 & 10.21 & 8.32 & 7.13 & 9.28 & 7.84 \\
\hline $\mathrm{F}$ & 0.81 & 0.91 & 0.90 & 0.31 & 0.15 & 0.37 & 0.11 \\
\hline $\mathrm{Cl}$ & 0.00 & 0.01 & 0.02 & 0.00 & 0.03 & 0.01 & 0.00 \\
\hline $\mathrm{H}_{2} \mathrm{O}$ calc. & 4.20 & 4.08 & 4.13 & 4.50 & 4.60 & 4.47 & 4.60 \\
\hline $\mathrm{O}=(\mathrm{F}, \mathrm{Cl})$ & 0.34 & 0.34 & 0.38 & 0.13 & 0.07 & 0.16 & 0.05 \\
\hline Total & 100.64 & 99.44 & 100.38 & 100.56 & 100.78 & 101.03 & 100.63 \\
\hline \multicolumn{8}{|l|}{ apfu } \\
\hline $\mathrm{Si}^{4+}$ & 6.41 & 6.41 & 6.42 & 6.57 & 6.53 & 6.51 & 6.41 \\
\hline $\mathrm{Al}^{\mathrm{IV}}$ & 1.59 & 1.59 & 1.58 & 1.43 & 1.47 & 1.49 & 1.59 \\
\hline $\mathrm{Al}^{\mathrm{VI}}$ & 3.81 & 3.78 & 3.79 & 3.86 & 3.89 & 3.86 & 3.90 \\
\hline $\mathrm{Ti}^{4+}$ & 0.01 & 0.01 & 0.01 & 0.00 & 0.00 & 0.00 & 0.00 \\
\hline $\mathrm{Fe}^{2+}$ & 0.14 & 0.16 & 0.14 & 0.11 & 0.15 & 0.11 & 0.14 \\
\hline $\mathrm{Cr}^{2+}$ & 0.00 & 0.00 & 0.00 & 0.00 & 0.00 & 0.00 & 0.00 \\
\hline $\mathrm{Mn}^{2+}$ & 0.00 & 0.00 & 0.01 & 0.02 & 0.02 & 0.02 & 0.02 \\
\hline $\mathrm{Mg}^{2+}$ & 0.04 & 0.05 & 0.06 & 0.04 & 0.05 & 0.03 & 0.06 \\
\hline $\mathrm{Ca}^{2+}$ & 0.01 & 0.01 & 0.01 & 0.04 & 0.06 & 0.01 & 0.06 \\
\hline $\mathrm{Na}^{1+}$ & 0.04 & 0.04 & 0.05 & 0.03 & 0.04 & 0.03 & 0.02 \\
\hline $\mathrm{K}^{1+}$ & 1.69 & 1.71 & 1.71 & 1.37 & 1.17 & 1.53 & 1.29 \\
\hline $\mathrm{F}^{1-}$ & 0.67 & 0.76 & 0.74 & 0.25 & 0.12 & 0.30 & 0.09 \\
\hline $\mathrm{Cl}^{1-}$ & 0.00 & 0.01 & 0.01 & 0.00 & 0.00 & 0.00 & 0.00 \\
\hline $\mathrm{OH}^{1-}$ & 3.67 & 3.62 & 3.62 & 3.87 & 3.93 & 3.85 & 3.96 \\
\hline $\mathrm{O}$ & 24 & 24 & 24 & 24 & 24 & 24 & 24 \\
\hline $\mathrm{Fe} /(\mathrm{Fe}+\mathrm{Mg})$ & 0.77 & 0.75 & 0.71 & 0.74 & 0.74 & 0.80 & 0.71 \\
\hline
\end{tabular}

Hub-24, 27, 30 - white mica, slightly greisenized topaz-albite granite, Hub-18, 19, 38, 41 - illite, argillized granite, Hub stock.

0.10 apfu) occurs in dickite from argillized granites. Smectite from these granites is partly enriched in Fe (0.25 apfu) and Ca (0.15 apfu) (Fig. 15). Chemical data for tosudite obtained by the EMPA are presented in Table 6. Compared to tosudite compositions from the published data (Brown et al., 1974; Nishiyama et al., 1975; Creach et al., 1986; Foord et al. 1986; Dudoignon et al., 1988; Merceron et al., 1988; de Pablo-Galan and Chávez-Garcia, 1994; Bartier et al., 2008), the octahedral occupancy on the basis of 36 (O, $\mathrm{OH})$ is partly higher $(7.98-8.36)$ relative to the published data (7.35-8.58). However, the amounts of $\mathrm{Mg}(0.03-0.11), \mathrm{Ca}(0.03-0.10), \mathrm{Na}(0.01)$ and $\mathrm{K}(0.03-0.33)$ in the analysed tosudite are lower than those in tosudite from the literature. When plotted in a $\mathrm{Mg}-{ }^{\mathrm{VI}} \mathrm{Al}-\mathrm{Fe}^{2+}$ diagram, the analysed tosudite from argillized granites as well as tosudites reported from other sites plot close to the ${ }^{\mathrm{VI}} \mathrm{Al}$ corner, confirming the dioctahedral character of the chlorite interlayer (Fig. 16).

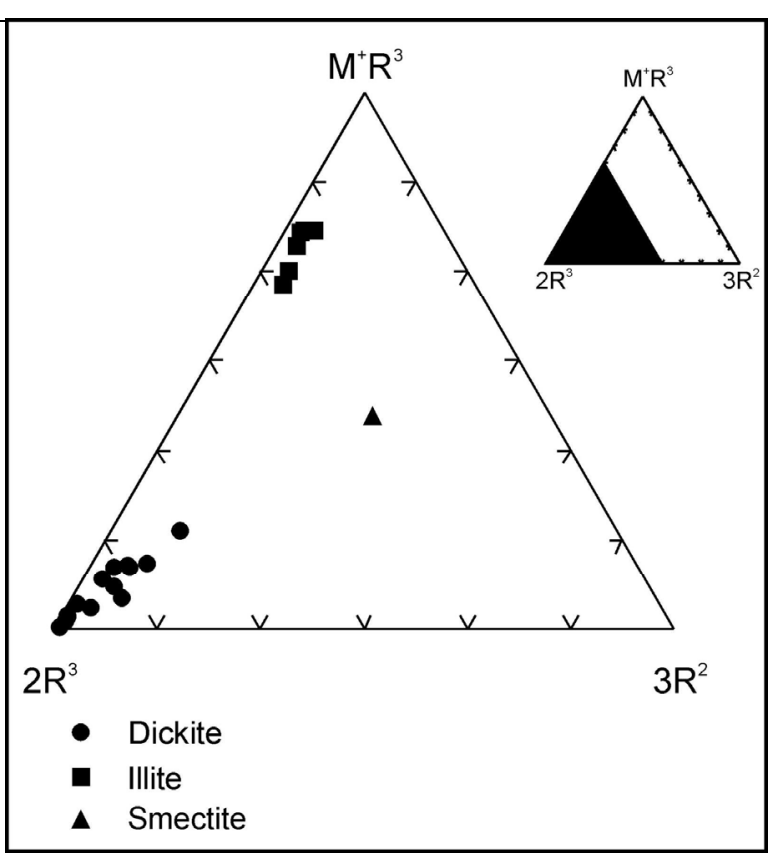

Fig. 15 Composition of clay minerals from argillized granites projected onto the $\mathrm{MR}_{3}-2 \mathrm{R}_{3}-3 \mathrm{R}_{2}$ triangle (Velde, 1977). 
Table 5 Representative analyses of clay minerals from argillized granites of the Hub stock.

\begin{tabular}{|c|c|c|c|c|c|}
\hline wt. $\%$ & Hub-13 & Hub-30 & Hub-34 & Hub-36 & Hub-40 \\
\hline $\mathrm{SiO}_{2}$ & 46.80 & 46.92 & 44.16 & 39.52 & 53.99 \\
\hline $\mathrm{TiO}_{2}$ & 0.00 & 0.02 & 0.00 & 0.00 & 0.00 \\
\hline $\mathrm{Al}_{2} \mathrm{O}_{3}$ & 38.61 & 38.01 & 40.49 & 45.06 & 17.72 \\
\hline $\mathrm{Cr}_{2} \mathrm{O}_{3}$ & 0.01 & 0.00 & 0.02 & 0.00 & 0.00 \\
\hline $\mathrm{FeO}$ & 0.30 & 0.23 & 1.50 & 1.43 & 3.13 \\
\hline $\mathrm{MnO}$ & 0.00 & 0.06 & 0.14 & 0.11 & 0.02 \\
\hline $\mathrm{MgO}$ & 0.07 & 0.08 & 0.36 & 0.06 & 2.09 \\
\hline $\mathrm{CaO}$ & 0.15 & 0.08 & 0.41 & 0.08 & 1.49 \\
\hline $\mathrm{Na}_{2} \mathrm{O}$ & 0.04 & 0.05 & 0.02 & 0.02 & 0.10 \\
\hline $\mathrm{K}_{2} \mathrm{O}$ & 0.20 & 0.06 & 0.24 & 0.36 & 0.18 \\
\hline $\mathrm{F}$ & 0.09 & 0.08 & 0.03 & 0.00 & 0.59 \\
\hline $\mathrm{Cl}$ & 0.00 & 0.01 & 0.01 & 0.00 & 0.13 \\
\hline $\mathrm{H}_{2} \mathrm{O}$ calc. & 13.88 & 13.80 & 13.90 & 13.74 & 12.27 \\
\hline $\mathrm{O}=(\mathrm{F}, \mathrm{Cl})$ & 0.04 & 0.04 & 0.01 & 0.00 & 0.28 \\
\hline Total & 100.11 & 99.36 & 101.27 & 100.38 & 91.43 \\
\hline \multicolumn{6}{|l|}{ apfu } \\
\hline $\mathrm{Si}^{4+}$ & 4.03 & 4.06 & 3.81 & 3.45 & 7.35 \\
\hline $\mathrm{Al}^{\mathrm{IV}}$ & 0.00 & 0.00 & 0.20 & 0.55 & 0.65 \\
\hline $\mathrm{Al}^{\mathrm{VI}}$ & 3.92 & 3.88 & 3.91 & 4.08 & 2.19 \\
\hline $\mathrm{Ti}^{4+}$ & 0.00 & 0.00 & 0.00 & 0.00 & 0.00 \\
\hline $\mathrm{Fe}^{2+}$ & 0.02 & 0.02 & 0.11 & 0.10 & 0.36 \\
\hline $\mathrm{Cr}^{2+}$ & 0.00 & 0.00 & 0.00 & 0.00 & 0.00 \\
\hline $\mathrm{Mn}^{2+}$ & 0.00 & 0.00 & 0.01 & 0.01 & 0.00 \\
\hline $\mathrm{Mg}^{2+}$ & 0.01 & 0.01 & 0.05 & 0.01 & 0.42 \\
\hline $\mathrm{Ca}^{2+}$ & 0.01 & 0.01 & 0.04 & 0.01 & 0.22 \\
\hline $\mathrm{Na}^{1+}$ & 0.01 & 0.01 & 0.00 & 0.00 & 0.03 \\
\hline $\mathrm{K}^{1+}$ & 0.02 & 0.01 & 0.03 & 0.04 & 0.03 \\
\hline $\mathrm{F}^{1-}$ & 0.05 & 0.04 & 0.02 & 0.00 & 0.51 \\
\hline $\mathrm{Cl}^{1-}$ & 0.00 & 0.00 & 0.00 & 0.00 & 0.06 \\
\hline $\mathrm{OH}^{1-}$ & 7.98 & 7.98 & 7.99 & 8.00 & 7.72 \\
\hline$(\mathrm{O}, \mathrm{OH}$ & 18 & 18 & 18 & 18 & 24 \\
\hline $\mathrm{Fe} /(\mathrm{Fe}+\mathrm{Mg})$ & 0.71 & 0.63 & 0.70 & 0.93 & 0.46 \\
\hline
\end{tabular}

Hub-13, 30, 34, 36 - dickite, Hub-40 - smectite, argillized granite, Hub stock
Table 6 Representative analyses of tosudite from argillized granites of the Hub stock.

\begin{tabular}{lrrrrrr}
\hline wt. \% & \multicolumn{1}{c}{$\begin{array}{c}\text { Hub- } \\
\text { Hub- }\end{array}$} & \multicolumn{1}{c}{\begin{tabular}{c} 
Hub- \\
\multicolumn{1}{c}{ Hub- }
\end{tabular}} & \multicolumn{1}{c}{$\begin{array}{c}\text { Hub- } \\
\text { Hub- }\end{array}$} & \multicolumn{1}{c}{43} & \multicolumn{1}{c}{46} & \multicolumn{1}{c}{47} \\
\hline $\mathrm{SiO}_{2}$ & 46.27 & 43.76 & 42.61 & 41.96 & 40.56 & 44.36 \\
$\mathrm{TiO}_{2}$ & 0.00 & 0.02 & 0.00 & 0.02 & 0.00 & 0.01 \\
$\mathrm{Al}_{2} \mathrm{O}_{3}$ & 39.09 & 41.97 & 42.76 & 43.99 & 44.74 & 36.91 \\
$\mathrm{Cr}_{2} \mathrm{O}_{3}$ & 0.00 & 0.04 & 0.00 & 0.03 & 0.00 & 0.00 \\
$\mathrm{FeO}$ & 0.85 & 1.07 & 0.61 & 0.70 & 1.44 & 3.54 \\
$\mathrm{MnO}$ & 0.08 & 0.28 & 0.16 & 0.14 & 0.11 & 0.15 \\
$\mathrm{MgO}$ & 0.13 & 0.24 & 0.24 & 0.16 & 0.15 & 0.42 \\
$\mathrm{CaO}$ & 0.33 & 0.55 & 0.15 & 0.15 & 0.19 & 0.40 \\
$\mathrm{Na} 2$ & 0.04 & 0.02 & 0.02 & 0.02 & 0.03 & 0.02 \\
$\mathrm{~K}_{2} \mathrm{O}$ & 0.43 & 0.47 & 0.19 & 1.53 & 0.14 & 0.53 \\
$\mathrm{~F}$ & 0.03 & 0.00 & 0.01 & 0.02 & 0.00 & 0.00 \\
$\mathrm{Cl}$ & 0.01 & 0.00 & 0.00 & 0.01 & 0.03 & 0.03 \\
$\mathrm{H}_{2} \mathrm{O}_{\text {calc. }}$ & 13.97 & 14.07 & 13.89 & 13.50 & 13.88 & 13.57 \\
$\mathrm{O}=(\mathrm{F}, \mathrm{Cl})$ & 0.01 & 0.00 & 0.00 & 0.01 & 0.01 & 0.01 \\
$\mathrm{Total}$ & 101.22 & 102.49 & 100.64 & 98.41 & 101.26 & 99.93 \\
& & & & & &
\end{tabular}

\begin{tabular}{lcccccc} 
apfu & & & & & & \\
$\mathrm{Si}^{4+}$ & 7.93 & 7.46 & 7.36 & 7.17 & 7.01 & 7.84 \\
$\mathrm{Al}^{1 \mathrm{~V}}$ & 0.07 & 0.54 & 0.64 & 0.83 & 0.99 & 0.16 \\
$\mathrm{Al}^{\mathrm{VI}}$ & 7.83 & 7.89 & 8.06 & 8.02 & 8.11 & 7.52 \\
$\mathrm{Ti}^{4+}$ & 0.00 & 0.00 & 0.00 & 0.00 & 0.00 & 0.00 \\
$\mathrm{Fe}^{2+}$ & 0.12 & 0.15 & 0.09 & 0.10 & 0.21 & 0.52 \\
$\mathrm{Cr}^{2+}$ & 0.00 & 0.01 & 0.00 & 0.00 & 0.00 & 0.00 \\
$\mathrm{Mn}^{2+}$ & 0.01 & 0.04 & 0.02 & 0.02 & 0.02 & 0.02 \\
$\mathrm{Mg}^{2+}$ & 0.03 & 0.06 & 0.06 & 0.04 & 0.04 & 0.11 \\
$\mathrm{Ca}^{2+}$ & 0.06 & 0.10 & 0.03 & 0.03 & 0.04 & 0.08 \\
$\mathrm{Na}^{1+}$ & 0.01 & 0.01 & 0.01 & 0.01 & 0.01 & 0.01 \\
$\mathrm{~K}^{1+}$ & 0.09 & 0.10 & 0.04 & 0.33 & 0.03 & 0.12 \\
$\mathrm{~F}^{1-}$ & 0.03 & 0.00 & 0.01 & 0.02 & 0.00 & 0.00 \\
$\mathrm{Cl}^{1-}$ & 0.01 & 0.00 & 0.00 & 0.01 & 0.02 & 0.02 \\
$(\mathrm{O}, \mathrm{OH})$ & 36 & 36 & 36 & 36 & 36 & 36 \\
$\mathrm{Fe} /(\mathrm{Fe}+\mathrm{Mg})$ & 0.79 & 0.71 & 0.59 & 0.71 & 0.84 & 0.82 \\
\hline
\end{tabular}

Hub-14, 15, 42, 43, 46, 47 - tosudite, argillized granite, Hub stock

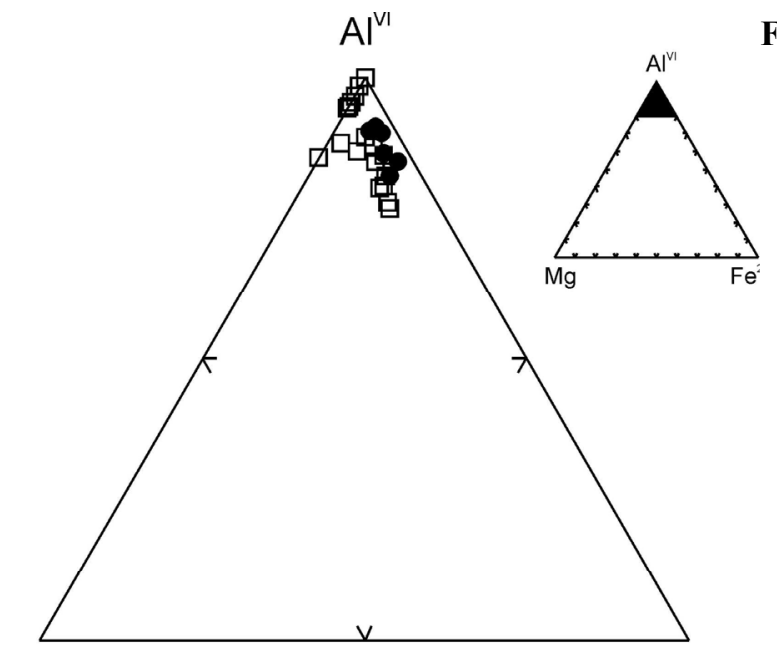

$\mathrm{Mg}$

$\mathrm{Fe}^{2+}$
- Tosudite, Hub stock

口 Tosudite, published data
Fig. 16 Composition of tosudite from argillized granites and other published tosudite data (Brown et al., 1974; Nishiyama et al., 1975; Creach et al., 1986; Foord et al. 1986; Dudoignon et al., 1988; Merceron et al., 1988; de Pablo-Galan and Chávez-Garcia, 1994; Bartier et al., 2008) in the gibbsitic interlayer.

\section{DISCUSSION}

The XRD analysis together with the DTA and TG analyses show that the dominant clay mineral in argillized granite is dickite accompanied by variable amounts of illite and tosudite. Chemical analyses also documented the presence of white mica. The presence of white mica (muscovite) and Li-mica (protolithionite) was acknowledged by microscopy of selected samples and by chemical analyses. The latter also confirm the presence of smectite. The clay mineral assemblage in argillized granites is very similar to that in fillings of quartz crystal cavities in the uppermost part of the Huber stock (Mach, 1979). The clay mineral assemblage in these cavities is 
dominated by dickite, with variable admixtures of white mica, illite and kaolinite.

Tosudite, a regularly interstratified mineral of dioctahedral chlorite and smectite, has been first found in the Kurata mine, Japan by Sudo et al. (1954). Later this mineral was found in some other hydrothermal alteration assemblages from Japan (e.g., Sudo and Kodama, 1957; Mitsuda, 1957; Haynashi, 1961; Shimoda, 1969). Frank-Kamenetsky et al. (1963) showed that the minerals designated as alushtite from Crimea are in some cases of the same type of interstratifications, and proposed the name tosudite for this mineral in honour to the first researcher Professor Toshio Sudo. In 1982, tosudite has been recognized as a separate species by the clay nomenclatural commission (Bailey, 1982). Tosudite was first recognized in various hydrothermal mineralizations from Japan (e.g., Kanaoka, 1968; Shimoda, 1969; Matsuda and Henmi, 1973; Nishiyama et al., 1975; Ichikawa and Shimoda, 1976). Later, tosudite was also recognized in argillized highly evolved granites from Massif Central, France (Creach et al., 1986; Dudoignon et al., 1988; Merceron et al., 1988, 1992) and in highly altered and argillized granite reached by drilling in the Rhine Graben, France (Ledésert et al., 1999; Bartier et al., 2008). These occurrences, especially the find of tosudite in hydrothermal altered topaz-albite granite from the Echassières granitic cupola (Merceron et al., 1988, 1992) are very similar to the clay mineral assemblage in the argillized granite of the Hub stock. However, topaz-albite granite and its argillized varieties from the Echassières stock are depleted in $\mathrm{SiO}_{2}$ (Fig. 7) and enriched in Li (Fig. 8) compared to granites from the Hub stock.

Petrographic observations suggest that greisenized granites of the Hub stock originated at the same time as the greisen bodies. Argillization of these granites was partly younger. The $\mathrm{p}-\mathrm{T}$ condition of greisenization in the Hub stock was estimated using a detailed fluid inclusion study (e.g., Dolníček et al. 2012). Fluid inclusions record almost continuously the post-magmatic cooling history of the Hub granite stock from $\sim 500$ to $<50{ }^{\circ} \mathrm{C}$. Greisenization was related to near-critical low-salinity ( $0-7$ wt. $\% \mathrm{NaCl}$ eq.) aqueous fluids with low amounts of $\mathrm{CO}_{2}, \mathrm{CH}_{4}$, and $\mathrm{N}_{2}$ ( $<10$ mol. \% in total) at temperatures of $\sim 350-400{ }^{\circ} \mathrm{C}$ and pressures of 300-530 bar. These fluids represent gas-enriched salt-poor steam exsolved from crystallizing granite, concentrating in the apical part of the Hub stock and, after cooling to near-critical conditions, causing pervasive greisenization. Few primary fluid inclusions from a partly younger quartz veins exhibit critical homogenization at temperatures of $374-393{ }^{\circ} \mathrm{C}$. Significant fluid activity post-dating the greisenization is also evidenced by abundant secondary fluid inclusions hosted in argillized granites. The secondary fluid inclusions show a very wide total range of homogenization temperatures (51$\left.355^{\circ} \mathrm{C}\right)$.
The physicochemical conditions of the origin of tosudite are noted only partly. Fransolet and Schreyer (1984) concluded that the possible thermal stability field for tosudite ranges from $150{ }^{\circ} \mathrm{C}$ to $350{ }^{\circ} \mathrm{C}$ at 1 kbar. Maksimović and Brindley (1980) demonstrated that the relatively high concentrations of $\mathrm{Si}$ and $\mathrm{Al}$ due to $\mathrm{pH}$ decrease to 4-6 are necessary for the formation of tosudite. However, Foord et al. (1986) specified possible thermal stability fields for tosudite, based on the synthetic studies of Eberl (1978 a, b), at $350-400{ }^{\circ} \mathrm{C}$. Therefore, the formation of tosudite in the argillized granites in the Hub stock could have occurred at $370-390{ }^{\circ} \mathrm{C}$. Lithium for the formation of tosudite in the Hub stock was probably supplied from greisens and greisenized granites containing large amounts of Li-mica. However, the concentrations of $\mathrm{Li}$ in Li-micas in topaz-albite granites from the Hub stock are distinctly lower than the Li concentrations in similar topaz-albite granites in other parts of the Krušné Hory/Erzgebirge Mts. (Fig. 12).

Primary fluid inclusions in the later quartzfluorite veins, also connected with the origin of quartz III in fine fissures (Fig. 6), show homogenization temperatures ranging from 185 to $90{ }^{\circ} \mathrm{C}$. The decrease in temperature was connected with a decrease in pressure (down to 50-100 bar), and mostly also with a decrease in salinity. The clay mineral assemblage (dickite, illite and very rare smectite) in argillized granites of the Hub stock very probably originated during this low-temperature phase. The very similar, late hydrothermal stage of clay mineral assemblage in the Echassières granitic cupola originated according to Merceron et al. (1992) at temperatures ranging from $450{ }^{\circ} \mathrm{C}$ to $150{ }^{\circ} \mathrm{C}$. The early alteration stage in the Echassières stock is represented by quartz, white mica, pyrophyllite, donbassite, tosudite and kaolinite, and the late stage is formed by quartz, fluorite, illite and smectite. A clay mineral assemblage formed by the illite-kaolinite-illite/smectite mixture with variable amounts of tosudite and corrensite was found in the Montebras granite cupola (Dudoignon et al., 1988). The diffraction reflections of $d$ (001) in a natural tosudite sample and in a sample after ethylene glycol treatment from both localities are similar to the diffraction reflections of tosudite from the Hub stock. However, the structure of both tosudite samples collapsed after heating to $500{ }^{\circ} \mathrm{C}$. Only a weak $9.94 \AA$ reflection occurs in tosudite from the Montebras granite cupola (Creach et al., 1986) and the value of $\mathrm{d}(001)$ gets reduced to $9.60 \AA$ occurs in tosudite from the Echassières granitic cupola (Merceron et al., 1988). As opposed to thermal behaviour of tosudite from granite cupolas in Massif Central, France, tosudite from Japan shows a similar thermal behaviour as tosudite from the Hub stock. When heated to $500{ }^{\circ} \mathrm{C}$, the reflection $\mathrm{d}(001)$ of tosudite from the Hokuno mine, Japan moved to $23.6 \AA$ and no rehydration occurred (Ichikawa and Shimoda, 1976). 


\section{CONCLUSIONS}

Distinctly argillized granites from the Hub stock contain a clay mineral assemblage formed by dickite, illite, tosudite and smectite. These granites occur in the upper part of the topaz granite stock, immediately beneath topaz-Li-mica greisens consisting of quartz, lithium mica (protolithionite) and topaz. Fluorapatite, zircon, Nb-Ta-Ti oxides, xenotime-(Y) and monazite(Ce) are rare accessory minerals. Compared to partly greisenized topaz-albite granites, the highly variable greisenized and argillized granites are enriched in $\mathrm{Si}$ (up to 78 wt. $\left.\% \mathrm{SiO}_{2}\right), \mathrm{Fe}\left(0.5-3\right.$ wt. $\% \mathrm{FeO}_{\text {tot. }}$ ), F (up to 1.6 wt.\%), Rb (830-1380 ppm), Li (515$2317 \mathrm{ppm}), \mathrm{Nb}(25-435 \mathrm{ppm})$ and $\mathrm{Ta}(21-64 \mathrm{ppm})$, but poor in Th (2-9 ppm), $\mathrm{Zr}$ (7-35 ppm) and bulk of REE (3-7 ppm). Newly recognized tosudite was identified on the basis of $d$ (001) $29.4 \AA$ XRD reflection on natural, oriented sample and $31.6 \AA$ reflection after ethylene glycol saturation. Li-micas from argillized granites are enriched in Li (0.83$1.12 \mathrm{apfu})$ and $\mathrm{F}$ (4.82-5.95 apfu) relative to those from slightly greisenized topaz-albite granites. Illite and white mica display very low amounts of phengite component.

Hydrothermal alteration identified in argillized granites of the Hub stock is relatively simple and corresponds to medium- to low-temperature alterations immediately post-dating massive greisenization of topaz-albite granites. Fluid inclusions record almost continuously the post-magmatic cooling history of the Hub granite stock from $\sim 500$ to $<50{ }^{\circ} \mathrm{C}$. The formation of tosudite in argillized granites of the Hub stock could have occurred at $370-390{ }^{\circ} \mathrm{C}$. Hydrothermal activity of Li-enriched solutions produced by alteration of Li-micas from partly greisenized topaz-albite granites and greisens of the Hub stock was satisfactory for the formation of tosudite. The later clay mineral assemblage (dickite, illite and smectite) originated together with fluoritequartz veins at temperatures between $90{ }^{\circ} \mathrm{C}$ and $185^{\circ} \mathrm{C}$.

\section{ACKNOWLEDGEMENTS}

The study was financially supported by the Czech Science Foundation (project No. 205/09/0540). We are grateful to $Z$. Korbelová from the Institute of Geology, v.v.i. of the Academy of Sciences of the Czech Republic for technical assistance in microprobe analyses and J. Nahunková from the Institute of Rock Structure and Mechanics, v.v.i of the Academy of Sciences of the Czech Republic for performing DTA and TG analyses. The detailed comments and recommendations of two journal reviewers helped to improve the initial draft of the manuscript. We highly appreciate the help of J. Adamovič for his English corrections.

\section{REFERENCES}

Bailey, S.W.: 1982, Nomenclature for regular interstratifications. Amer. Mineral., 67, 394-398.
Bartier, D., Ledésert, B., Clauer, N., Meunier, A., Liewig, N., Morvan, G. and Addad, A.: 2008, Hydrothermal alterations of the Soultz-sous-Forêts granite (Hot fractured rock geothermal exchanger) into a tosudite and illite assemblage. Eur. J. Mineral., 20, 131-142. DOI: $10.1127 / 0935-1221 / 2008 / 0020-1787$

Beran, P. and Sejkora, J.: 2006, The Krásno Sn-W ore district near Horní Slavkov: mining history, geological and mineralogical characteristics. J. Czech Geol. Soc., $51,3-42$.

Breiter, K.: 2002, From explosive breccia to unidirectional solidification textures: magmatic evolution of a phosphorus- and fluorine-rich granite system (Podlesí, Krušné hory Mts., Czech Republic), Bull. Czech Geol. Surv., 77, 67-92.

Breiter, K.: 2008, Mineral and textural evolution of subvolcanic A-type granite: Hora Svaté Kateřiny stock, Krušné Hory Mts., Czech Republic. Z. geol. Wiss., 36, 365-382.

Breiter, K., Förster, H.-J. and Seltmann, R.: 1999, Variscan silicic magmatism and related tin-tungsten mineralization in the Erzgebirge-Slavkovský les metallogenic province. Miner. Deposita, 34, 505-521. DOI: $10.0007 / \mathrm{s} 001260050217$

Brown, P., Bourguignon, P. and Thorez, J.: 1974, A lithiumbearing aluminian regular mixed layer montmorillonite-chlorite from Huy, Belgium, Clay Miner., 10, 135-144.

DOI: 10.1180/claymin.1974.010.3.01

Chappell, B.W., and Hine, R.: 2006, The Cornubian batholith: an example of magmatic fractionation on a crustal scale. Res. Geol., 56, 203-244. DOI: $10.1111 / \mathrm{j} .1751-3928.2006 . t b 00281 . x$

Creach, M., Meunier, A. and Beaufort, D.: 1986, Tosudite crystallization in the kaolinized granitic cupola of Montebras, Creuse, France. Clay Miner., 21, 225-230.

Dolejš, D. and Štemprok, M.: 2001, Magmatic and hydrothermal evolution of Li-F granites: Cínovec and Krásno intrusions, Krušné hory batholith, Czech Republic. Bull. Czech Geol. Surv., 76, 77-99.

Dolníček, Z., René, M., Prochaska, W. and Kováŕ, M.: 2012, Fluid evolution of the Hub stock, Horní Slavkov-Krásno Sn-W ore district, Bohemian Massif, Czech Republic. Mineral. Deposita, 47, 821-833. DOI: $10.1007 / \mathrm{s} 00126-012-0400-0$

Dudoignon, P., Beaufort, D. and Meunier, A.: 1988, Hydrothermal and supergene alterations in the granitic cupola of Montebras, Creuse, France. Clays and Clay Miner., 36, 505-520.

Eberl, D.: 1978 a, The reaction of montmorillonite to mixedlayer clay: The effect of interlayer alkali and alkaline earth cations. Geochim. Cosmochim. Acta, 42, 1-7.

Eberl, D.: 1978 b, Reaction series for dioctahedral smectites. Clays and Clay Miner., 26, 327-340.

Foord, E.E., Starkey, H.C. and Taggart, J.E.Jr.: 1986, Mineralogy and paragenesis of "pocket" clays and associated minerals in complex granitic pegmatites, San Diego County, California. Amer. Mineral., 71, 428-439.

Förster, H.-J., Tischendorf, G., Trumbull, R.B. and Gottesmann, B.: 1999, Late-collisional granites in the Variscan Erzgebirge. J. Petrol., 40, 1613-1645. DOI: $10.1093 /$ petroj/40.11.1613

Fransolet, A. M. and Schreyer, W.: 1984, Sudoite, di/trioctahedral chlorite: A stable low-temperature phase in the system $\mathrm{MgO}-\mathrm{Al}_{2} \mathrm{O}_{3}-\mathrm{SiO}_{2}-\mathrm{H}_{2} \mathrm{O}$. Contrib. Miner. Petrol., 86, 409-417. DOI: $10.1007 / \mathrm{BF} 01187144$ 
Frank-Kamenetsky, V., Logvinenko, N. and Drits, V.: 1963, Tosudite-a new mineral forming the mixed-layer phase in alushtite. Proc. Int. Clay Conf., 181-186.

Guidotti, C.V.: 1984, Micas in metamorphic rocks. Reviews in Mineralogy, 13, 357-468.

Haynashi, H.: 1961, Mineralogical study on alteration products from altered aureole of some "Kuroko" deposits. Min. J. Japan, 5, 12-18.

Ichikawa, A., and Shimoda, S.: 1976, Tosudite form the Hokuno mine, Hokuno, Gifu prefecture. Japan, Clays and Clay Miner., 24, 142-148.

Jarchovský, T.: 2006, The nature and genesis of greisen stocks at Krásno, Slavkovský les area - western Bohemia, Czech Republic. J. Czech Geol. Soc., 51, 201-214

Kanaoka, S.: 1968, Long spacing clay mineral in Uebi stone from Ehime Prefecture and Izushi stone from Hyogo Prefecture. J. Ceram. Ass., Japan, 11, 116-123.

Ledésert, B., Berger, G., Meunier, A., Genter, A.and Bouchet, A.: 1999, Diagenetic-type reactions related to hydrothermal alteration in the Soultz-sous-Forêts granite, France, Eur. J. Mineral., 11, 731-741.

Mach, Z.: 1979, Association of clay minerals with tintungsten mineralization in the surroundings of Krásno near Horní Slavkov. Acta Univ. Carol., Geol., 1979, 3-4, 105-122.

Maksimović, Z. and Brindley, G.W.: 1980, Hydrothermal alteration of a serpentinite near Takovo, Yugoslavia, to chromium-bearing illite/smectite, kaolinite, tosudite, and halloysite. Clays and Clay Miner., 28, 295-302.

Matsuda, T. and Henmi, K.: 1973, Hydrothermal behaviour of an interstratified mineral from the mine of Ebara, Hyogo Prefecture, Japan. (An example of changes from randomly interstratified clay mineral to regular one). J. Clay Science Soc., Japan, 13, 87-94.

Melka, K., Košatka, M. and Zoubková, J.: 1991, The occurrence of dioctahedral chlorite in greisen. In: Proc. $7^{\text {th }}$ Euroclay Conf. Dresden, 757-760.

Merceron, T., Inoue, A., Bouchet, A. and Meunier. A.: 1988, Lithium-bearing donbassite and tosudite from Echassières, Massif Central, France. Clays and Clay Miner., 36, 39-46. DOI: 10.1007/BF00310461

Merceron, T., Vieillard, P., Fouillac, A.-M. and Meunier A.: 1992, Hydrothermal alterations in the Echassières granitic cupola. Contrib. Mineral. Petrol., 112, 279292.

Mitsuda, T.: 1957, Long spacing clay mineral from the Uku mine, Yamaguchi Prefecture, Japan. Min. J., Japan, 2, 169-179.

Nishiyama, T., Shimoda, S., Shimosaka, K. and Kanaoka, S.: 1975, Lithium bearing tosudite. Clays and Clay Miner., 23, 337-342.

Pablo-Galan de, L. and Chávez-García, M.L.: 1994, Dioctahedral tosudite in hydrothermally altered pliocene rhyolitic tuff, Neutla, Mexico. Clays and Clay Miner., 42, 114-122.
Pechar, F. and Rykl, D.: 1992, Die Vergleichung der kristallchemischen Parameter der Fe-Li Gimmer aus den Lokalitäten Cínovec, Vysoký Kámen and des Biotits aus dem Mittelböhmischen Pluton. Ústecké muzej. seš., 4, 56-70, (in Czech).

Pouchou, J.J. and Pichoir, F.: 1985, "PAP" ( $\varphi-\rho-Z)$ procedure for improved quantitative microanalysis. In: Armstrong, J.T. (ed.), Microbeam Analysis, 104-106, San Francisco Press.

Pouliot, G., Barondeau, B., Sauve, P. and Davis, M.: 1978, Distribution of alteration minerals and metals in the Fire Tower zone at Brunswick tin mines Ltd., Mount Pleasant area, New Brunswick. Canad. Mineral., 16, 223-237.

Psyrillos, A., Mannig, D.A.C. and Burley, S.D.: 2001, The nature and significance of illite associated with quartzhematite hydrothermal veins in the St. Austell pluton, Cornwall, England. Clay Miner., 36, 585-597. DOI: $10.1180 / 0009855013640010$

René, M.: 1998, Development of topaz-bearing granites of the Krudum massif (Karlovy Vary pluton), Acta Univ. Carol., Geol., 42,103-109.

René, M. and Škoda, R.: 2011, Nb-Ta-Ti oxides fractionation in rare-metal granites: Krásno-Horní Slavkov ore district, Czech Republic. Mineral. Petrol., 103, 37-48. DOI: 10.1007/s00710-011-0152-z

Reynolds, R.C.: 1988, Mixed-layer chlorite minerals, In: Bailey, S.W. and Ribbe, P.H. (eds.) Hydrous Phyllosicilates, Reviews in Mineralogy, 601-629.

Sainsbury, C.L.: 1960, Metallization and post-mineral hypogene argillization, Lost river tin mine, Alaska. Econ. Geol., 55, 1478-1506.

Shimoda, S.: 1969, New data for tosudite. Clays and Clay Miner., 17, 179-184.

Sudo, T. and Kodama, H.: 1957, An aluminous mixed-layer mineral of montmorillonite-chlorite. Z. Kristallogr., 109, 379-387.

Sudo, T., Takahashi, H. and Matsui, H.: 1954, A long spacing at about $30 \mathrm{KX}$, confirmed from a fireclay, Nature, 173, 261-262.

Taylor, S.R. and McLennan, S.M.: 1985, The continental crust: Its composition and evolution, Oxford. Blackwell, $312 \mathrm{p}$.

Tischendorf, G., Gottesmann, B., Förster, H.-J. and Trumbull, R.B.: 1997, On Li-bearing micas estimating $\mathrm{Li}$ from electron microprobe analysis and improved diagram for graphical representation. Mineral. Mag., 61, 809-834.

Velde, B.: 1977, Clays and clay minerals in natural and synthetic systems, Amsterdam. Elsevier, 325 pp. 